\title{
Analysis of value portfolios in the Brazilian market*
}

\author{
Vitor Palazzo ${ }^{1}$ \\ (D) https://orcid.org/0000-0002-3829-197X \\ Email: vitorpalazzo@gmail.com
}

José R. F. Savoia ${ }^{2}$

Email: jrsavoia@usp.br

José Roberto Securato ${ }^{2}$

Email: securato@usp.br

Daniel Reed Bergmann²

Email: danielrb@usp.br

${ }^{1}$ Fundação Instituto de Administração, Laboratório de Finanças, São Paulo, SP, Brazil

${ }^{2}$ Universidade de São Paulo, Faculdade de Economia, Administração e Contabilidade, Departamento de Administração, São Paulo, SP, Brazil

Received on 12.14.2016 - Desk acceptance on 01.11.2017 - $4^{\text {th }}$ version approved on 01.14.2018 - Ahead of print on 07.16.2018

Associate Editor: Fernanda Finotti Cordeiro Perobelli

\section{ABSTRACT}

This paper tested a value investing strategy for the Brazilian market, selecting stocks based on the criteria suggested by Graham (2007) so that lower quality companies with potential risks not captured by the traditional risk models were eliminated. Five hundred thirty-two stocks were analyzed in the period from May 2005 to April 2015 and, after applying the Graham selection filters, portfolios with 10-year maturity were obtained. After simulating the portfolios' performances over the analysis period and measuring the Sharpe ratios, it was possible to verify: (i) the validity of the Graham model for selecting stocks in the Brazilian market, (ii) tiering of the Graham filters according to their relevance, and (iii) the ideal composition for a value investing portfolio in the Brazilian market for the period analyzed. The portfolios obtained were able to offer higher risk adjusted returns than the Bovespa Index in the period, as well as lower risk metrics. The results confirmed the validity of the value investing strategy in the domestic market.

Keywords: value investing, investments, stocks, investment philosophies, Brazilian market.

Butantã - São Paulo - SP - Brazil

*Article presented at the XVI Brazilian Finance Meeting, Rio de Janeiro, RJ, Brazil, July 2016. 


\section{INTRODUCTION}

Over the years, various strategies have been developed for investing in stocks, many of which can be grouped according to their basic assumptions with regard to prices and the behavior of economic agents. These groups of strategies are often named after investment philosophies (Damodaran, 2007).

Fama (1970) argued that when investing in stocks there would be no possibility of earning higher returns than the market average unless higher risks were assumed. Investors who believe in this assumption should practice index investing: investing in the theoretical portfolio of investments used as an average market performance index. Investors who do not believe in market efficiency seek to obtain higher performance, adopting investment philosophies based either on timing (trying to buy and sell stocks at opportune moments) or on stock picking (favoring stocks with better performance prospects than the market average).

In timing strategies, investors seek indicators of the best moments to buy or sell stocks, reading charts or using statistical indicators and searching for patterns of market behavior.

In stock picking, one classification offered by studies such as those of Nicholson $(1960,1968)$ and Fama and French (1992) is the classification of companies based on their price-to-earnings $(\mathrm{P} / \mathrm{E})$ or price-to-book value $(\mathrm{P} / \mathrm{B})$ ratios. Stocks that offer lower than average $\mathrm{P} / \mathrm{E}$ and $\mathrm{P} / \mathrm{B}$ are called value stocks, in reference to value investing, an investment philosophy developed by Benjamin Graham, who argued in favor of buying companies with low $\mathrm{P} / \mathrm{E}$ and P/B levels. Stocks that have higher ratios than the market average are called growth stocks, since their ratios would be justified due to their above-market-average growth prospects.

Investors in value stocks are those who seek to identify undervalued stocks in order to invest in them and take long term positions (Damodaran, 2007). Basu (1977), Jaffe, Keim, and Westerfield (1989), Chan, Hamao, and Lakonishok (1991), and Fama and French (1992) claimed that value stocks presented higher returns and lower risks, an effect known as value premium. In contrast, Sharpe (1966) and Jensen (1968) found evidence of lower performance than that of the market index when adjusted for the risk of investment funds that sought underpriced assets.

Lakonishok, Shleifer, and Vishny (1994) argued that a value premium occurs because value investment strategies favor investment in companies that are less desired by investors. Haugen (1995) states that the observed effect is due to the fact that value stocks are able to restructure and redirect their businesses.

Value premium was observed by Fama and French (2005) both in large and small companies. Similarly, Basu (1983) had already diagnosed that discounts in terms of companies' $\mathrm{P} / \mathrm{E}$ were more relevant for subsequent above-market-average performance than company size.

Fama and French $(1992,1998)$ and Campbell, Polk, and Vuolteenaho (2010) explain the observed effect by saying that value stocks are fundamentally riskier, but this risk is not measured by the traditional market parameters, and for this reason they do not present higher betas. However, Chan and Lakonishok (2004) argue that the superiority of value stocks is due to investors behavior, and not due to higher risks.

The use of value premium to benefit Brazilian investors is one of the reasons for this paper. When seeking to apply value investing as an investment strategy, it is important to understand that besides selecting companies with lower P/E and P/B levels, Graham would suggest following additional criteria that can be summarized in accounting and financial ratios. These indicators are called the Graham filters or value filters.

The obtainment of above-market-average performance using his criteria has been observed by Oppenheimer (1984), Klerck and Maritz (1997), Passos and Pinheiro (2009), Artuso and Chaves (2010), Almeida, Oliveira, Botrel, and Martins (2011), and Testa (2011). However, none of the studies was concerned with adapting the Graham filters to the economic reality at the time the stocks were selected.

Since stock selection methodologies at one market moment can become obsolete with changes in market conditions (Damodaran, 2006), or when used in a different market, and taking into account that the criteria suggested by Graham were elaborated in the 1970s and for the North American market, the economic context in which the strategies are applied should be analyzed.

Thus, this study not only aims to verify the validity of the stock selection model proposed by Graham in the Brazilian market, but to also go further in questions that have been scarcely explored by the previous studies. Since the studies conducted in the domestic market differ from each other in terms of the criteria used for choosing stocks and have not provided adaptations based on economic fundamentals in order to improve stock selection, this article aims to offer an approach that unites the criteria 
to be used when picking stocks based on the original proposal from Graham, with adaptations based on the current characteristics of the domestic market. Therefore, the general aim of this paper is to verify whether the value investing strategy is applicable and produces greater results in the Brazilian market for the period analyzed.

Markowitz (1952) states that the portfolio selection process can be divided into two stages: the first begins with observation and experience and ends with beliefs regarding the future performance of the assets available for investment; the second starts with beliefs about future performance and ends with the portfolio being chosen. Using the filters proposed by Graham, the first stage of portfolio selection was developed, and using the modern theories of portfolio elaboration, the second stage was carried out.

The text is organized into five sections, including this introduction. Next, the literature review on the topic is carried out, highlighting previous studies. The third section discusses the methodology and research techniques used. Then the results are presented, followed by the conclusions of the study.

\section{LITERATURE REVIEW}

\subsection{Value Investing}

The main concept of value investing consists of being able to determine the real value of businesses that are potential investment targets based on concrete data, their intrinsic values. The ideas of value investing were conceived by Benjamin Graham and David Dodd in 1934 in the book Security analysis (Graham \& Dodd, 2009), in which the authors explained how investments should be evaluated and how a margin of safety should be established when investing - a key concept for mitigating investment risks.

Graham was not only a professor at Columbia University for many years, but he also put his investment theory into practice by creating an investment management company: Graham-Newman. In his business, Graham used various investment methodologies, all of which were based on value investment concepts in terms of trying to buy assets for less than they were worth.

Subsequent to Graham, other investors were influenced by his core ideas and developed their own investment methodologies. Greenwald, Kahn, Sonkin, and Biena (2001) offer the classification of these new approaches between classic value investing (based on the value of tangible assets and with a widely diversified portfolio), contemporary value investing (based on the value of a brand or single product and with a highly concentrated portfolio), and mixed value investing (based on the replacement value of a company's goods or on their relative value), and portfolios can have different levels of diversification. Other classifications can also be seen, such as active value investing (regarding activist investors) or deep value investing (YEE, 2008) (to describe investors that buy heavily discounted stocks).

In the latest edition of The intelligent investor, edited between the end of 1971 and the beginning of 1972 (the translated Brazilian edition was published in 2007), Graham (2007, p. 386) listed seven requirements for a stock to be acquired:

1. Adequate size: minimum revenue of US\$ 100 million for industrial companies and minimum total assets of US\$ 50 million for public utility.

2. Sufficiently strong financial conditions.

a. In industrial companies: current assets should be at least double current liabilities (current ratio). Long term debt should not exceed the company's working capital (current assets - current liabilities); b. In public utility: debt should not exceed twice the stock equity (at book value);

3. Uninterrupted dividend payments for at least the last twenty years;

4. No losses in the last ten years, only profits;

5. Minimum growth of at least one-third in per-share earnings in the least ten years;

6. Current price should not be more than 15 times average earnings in the last three years;

7. Current price should not be more than 1.50 times the book value of net equity.

Since it is possible that the last filter is severely restrictive, Graham stated that "a multiplier of earnings below 15 could justify a correspondingly higher multiplier of assets. As a rule of thumb, we suggest that the produt of the multiplier times the ratio of price to book value should not exceed 22.50".

It will be verified in what way this list of criteria can be applied in the Brazilian market and what kind of adjustments are necessary for these criteria to fit the reality of Brazilian equity market. 


\subsection{Previous Studies}

Rea (1977) stated that Graham imagined that the most important filters were those related to the earnings offered by stocks (such as a low P/E). Non-documented studies by Graham would have proven that using these criteria alone with low debt ratio would generate a portfolio with almost as good a performance as a portfolio with other additional criteria.

Oppenheimer (1984) verified that portfolios compiled and revised annually of companies that fit the value criteria would have obtained above-market-average performance between 1974 and 1981. Using similar criteria, Klerck and Maritz (1997) observed the same results between 1977 and 1994.

Using more similar criteria to those suggested by Graham (2007), Passos and Pinheiro (2009) obtained a portfolio with a performance of $566 \%$ compared to $219 \%$ for the Bovespa Index (Ibovespa) between 2001 and 2005, thus favoring the technique suggested by Graham.

Various studies analyzed had to deal with the challenge of finding stocks that fulfilled all the suggested criteria, such as in the case of Artuso and Chaves (2010). Thus, these authors did not take into consideration the cutoff levels suggested by Graham, but instead divided the sample of companies into quartiles, determining that the cut-off level for picking companies would be the multiple observed in the most attractive quartile for each criterion. Similarly, these authors claimed that the portfolios elaborated using the value criteria were superior to the Ibovespa, thus proving the superiority of the methods suggested by Graham.

Almeida et al. (2011) and Testa (2011) also obtained results that favored and reinforced the validity of the value investing methodology.

\subsubsection{Value investing portfolios: diversification.}

Graham and Dodd (2009) were in favor of diversification. However, as the authors did not formalize specific guidelines regarding portfolio elaboration, their vision with respect to diversification is based on research of secondary sources, such as biographies.

Graham recommended that investors diversify for two reasons: the first would be to reduce the risk that an erroneous analysis of a particular stock could involve, and the second would be to mitigate the liquidity risk of the positions acquired (as a way of managing the risk of having stocks with little liquidity).

As observed by recent studies that a small number of different stocks already lead to a substantial reduction in non-systematic risk, in this paper the diversification level of 10 assets will be used. The second risk factor will be managed in the domestic market by adding a filter to the Graham model, restricting the selection to the most liquid stocks on the Brazilian stock exchange.

\section{METHODOLOGY}

\subsection{Portfolio Selection}

Based on the definition that investors wish to maximize their expected return and minimize their risk (variance), Markowitz (1952) clarified how the composition of a portfolio with more than one asset promoted a reduction in total portfolio risk.

Authors such as Evans and Archer (1968) and Fischer and Lorie (1970) observed that eight assets are able to eliminate the most significant portion of non-systemic risk, and there does not appear to be any reason for the investor to construct a portfolio with more than 10 assets.

In Brazil, Brito (1981) found that the benefits of diversification could be observed in portfolios with around eight assets, and the gains from diversification became negligible for portfolios with more than 15 stocks. Ceretta and Costa (1998) verified that between 1992 and 1997 a naïve portfolio with 12 stocks would eliminate more than $52 \%$ of the risk of a typical stock and $83 \%$ of the risk that could be eliminated by diversification. Martins and Gava (2009) verified that from 1996 to 2008 a portfolio composed of only six stocks would be enough to present a lower risk than the Ibovespa.

Battaglia (2013) observed that naïve portfolios of 10 assets surpassed various investment funds with active management. Santiago and Leal (2014) concluded that naïve portfolios with six to 16 stocks are attractive for small individual investors. Due to these studies, analyses were done using portfolios composed by 10 assets.

The development of Markowitz's theory (1952) has shown that there are optimal portfolio compositions that provide the best expected risk/return ratio for investors. Alternatively to the model for elaborating portfolios that aim to maximize the mean-variance relationship, other models have emerged.

Bloomfield, Leftwich, and Long (1977) found that the use of more sophisticated portfolio formation techniques 
implies a higher estimation cost, and the use of more sophisticated techniques does not lead to significantly higher results for any amount of assets. DeMiguel, Garlappi, and Uppal (2009) tested 14 portfolio optimization models and concluded that none of them was consistently better than naive diversification, which indicated that the gains from diversification using "optimal" portfolios are outweighed by the implicit estimation errors.

Within the domestic context, Thomé, Leal, and Almeida (2011), Battaglia (2013), Santiago (2013), and Santiago and Leal (2014) argued that $1 / \mathrm{N}$ portfolios often obtain better results. The strong evidence presented in the study by DeMiguel et. al. (2009) favors the understanding that naive portfolios offer reasonably attractive results in terms of risk and return.

Thus, it can be inferred that the most adequate methodology for determining the relative participation of each asset in a portfolio is naive diversification, this being the methodology adopted in the elaboration of a portfolio from the value investing perspective.

\subsection{Data Collection}

Using the Economatica ${ }^{\circledR}$ system database, an analysis was initially carried out to verify the applicability of the Graham filters in the domestic market and at what thresholds they should be established. The interval between January of 1995 and December of 2004 (analysis period) was used to analyze the past behavior of the companies and their multiples. All stocks that presented at least one trade over the course of 2004 were considered valid for analysis, thus totaling 313 companies with 532 stocks. As the results from the last quarter of a given year are only published at the start of the following year (generally by mid-April), the portfolios were composed on the base date of April $29^{\text {th }}$ of 2005 (it was considered that the stocks were bought at the closing price of the April $29^{\text {th }}$ trading session, so that their first day of returns was the next working day: May $2^{\text {nd }}$ of 2005). With this, the aim was to measure the returns obtained from May of 2005 onwards, with their parameters being evaluated up to April $30^{\text {th }}$ of 2015 (verification period), resulting in a total of 10 years (or 120 months). As value investing supports a passive investment approach and investments that reach maturity after long time horizons, the portfolios elaborated on April $29^{\text {th }}$ of 2005 were maintained for the whole verification period.

Once the portfolio of companies that fits each criterion to be analyzed was established, portfolios were elaborated with only one stock from each company: the most liquid, based on the financial volume traded over 2004. This measure was adopted due to the understanding that buying more than one stock from the same company would not promote an expected dilution of risk in the composition of the portfolio. All the portfolios elaborated were naïve portfolios.

In the case of selected stocks that ceased to trade over the verification period, in order to eliminate the survival biases, it was considered that the resources that were invested in them were reinvested in the portfolio according to its composition at the time the stock was delisted, aiming to measure the total return provided by the portfolio.according to the hedge fund principle of reinvesting proceeds and premiums. This principle was used seeking comparability of the suggested strategy with portfolio management in the Brazilian market in products such as investment funds. As investment funds do not need to pay income tax when selling stocks, thus being able to reinvest the financial value in other investments, the payment of income tax was not considered even in the case of the delisting of stocks. Similarly, all the financial values from the proceeds paid by the stocks net of taxes were reinvested in the same stock (aiming to measure the absolute return from the stock).

In order to analyze the filter suggested by Graham in the Brazilian market, the cut-off level for each one of the filters was adjusted according to the need to contextualize and adapt to the local market, which will be described in more detail in the next section. This care was taken due to Graham having created them in the 1970s in particular market conditions that were different from the current ones.

On the date of portfolio composition, it was verified which stocks fulfilled each one of the filters. After this, a portfolio with the 10 most liquid stocks for each criterion was compiled and its performance in the verification period was analyzed. The relevance of each one of the filters was analyzed in terms of the dominance of the resulting portfolios over the Ibovespa in terms of average annual return, standard deviation (SD) (volatility), Sharpe ratio, beta, and Jensen's alpha.

After this, a portfolio was elaborated with all the filters together. Based on the stocks that passed through all the filters, only the 10 most liquid ones were chosen. This analysis aimed to identify the degree of synergy between the filters when used together.

Finally, the analyses were carried out by removing the filters one by one from the stock selection and verifying what the resulting portfolios were. Based on these new selections, portfolios with the 10 most liquid stocks were elaborated again to determine which filters presented the greatest relevance in the stock selection. In all the scenarios and compositions simulated here, the effects 
of taxes and transaction costs were not considered. All the portfolios resulting from the application of the filters are attached to this paper.

\subsection{Filter 1: Turnover}

In order to establish a selection criterion for large companies, the criterion of the federal legislation in Brazil (article 3 of Act 11,628 of 2007), which defines large companies as those that present "annual or annualized gross operating revenue of more that $\mathrm{R} \$$ $300,000,000.00$ (three hundred million reais)" was used as the basis. For 2004, restricting the analysis universe to only companies with revenues above $\mathrm{R} \$ 300$ million would not be excessively restrictive, since it would enable the selection of 220 companies for subsequent analysis of the other filters.

\subsection{Filter 2: Current Ratio}

A coherent cut-off threshold for companies could become the object of a long discussion, since various sectors could require different treatments. However, as suggested by Graham, the stock selection model should be the same for the whole market, without sectoral discriminations.

From analyzing the companies that presented a current ratio in 2004, the median obtained was 1.22 , with 207 companies lying above this threshold. Thus, it was understood that it would be coherent to use this level to select the companies without it being excessively restrictive in the stock selection, and so this was the one used in the filter applied.

\subsection{Filter 3: Uninterrupted Profits}

One of the most emphasized aspects in value investing is the history of company earnings being relatively constant and resistant to shocks caused by business cycles. Taking 2004 as the base year, 287 companies reported a profit. Of these, 164 presented only profits in the last three years,
129 presented only profits in the last five years, and 43 remained profitable for the last 10 years. With the aim of defining an adequate time horizon for uninterrupted profits, it can be deduced that restricting the analysis to those that remained profitable in the last five years appears to be adequate, since this would result in 129 companies for analyses of the other filters.

\subsection{Filter 4: Historical Dividend Payment}

Analyzing the period of available data in the Brazilian market with relation to the stocks that paid dividends, in 2004, 292 were observed that paid dividends in the last three years, 231 in the last five years, 164 in the last seven years, and 84 in the last 10 years.

Despite Graham having suggested a minimum time horizon of 20 years, it was observed that this horizon could be excessively restrictive for the domestic market on the date chosen. As the minimum time horizon required for consecutive profits was five years, it is understood that it is important to maintain the same period for selecting dividend paying stocks, thus avoiding companies that were not profitable, but also including those that paid out profit reserves, as well as companies that were able to obtain profits but that did not pay out dividends.

\subsection{Filter 5: Annual Growth of Earnings per Share}

Thinking of business continuity, Graham required companies to present a minimum 10 -year growth of $30 \%$, equivalent to an annual mean of $2.66 \%$. In an attempt to implement the same metric in Brazil, an analysis was carried out of the average rate of earnings growth in the last 10 years, only taking into consideration stocks that presented positive earnings per share in 1994, with the aim of eliminating possible biases due to a negative base value. For 2004 it was verified how many stocks met the different criterion levels for minimum annual rate growth (Table 1). 
Table 1

Average annual growth rates (from 1995 to 2004)

\begin{tabular}{|c|c|c|c|}
\hline $\begin{array}{c}\text { Minimum annual growth rate } \\
(\%)\end{array}$ & $\begin{array}{l}\text { Number of stocks } \\
\text { (n) }\end{array}$ & $\begin{array}{c}\text { Minimum annual growth rate } \\
(\%)\end{array}$ & $\begin{array}{l}\text { Number of stocks } \\
\text { (n) }\end{array}$ \\
\hline$<-30$ & 255 & 2.66 & 182 \\
\hline-30 & 248 & 5 & 169 \\
\hline-20 & 233 & 10 & 145 \\
\hline-10 & 210 & 20 & 94 \\
\hline 0 & 194 & 30 & 46 \\
\hline
\end{tabular}

Source: Economatica ${ }^{\circledR}$.

The first field in Table $1(<-30 \%)$ involves the total stocks with available data on earnings per share in the period. The following fields present how many companies had higher growth rates than the levels established. It is perceived that requiring at least $2.66 \%$ annual growth in earnings per share, in the same way as suggested by Graham, does not appear to be excessively restrictive, since this would leave 182 stocks eligible for the other analyses, and so this was the criterion adopted.

\subsection{Filter 6: Price/Earnings (P/E)}

Graham considered it valid to analyze the earnings/ price ratio (earning yield) of a stock to evaluate its attractiveness as an investment. This ratio should be compared with the nominal return offered by risk free fixed income securities. Comparing the levels of return offered by the North American market at the time Graham formulated the filters and the time in which the stock portfolio selection date was established for this study, Table 2 was reached.

Table 2

Comparison of price/earnings (P/E) and returns: United States of America in 1971 and Brazil in 2004

\begin{tabular}{|c|c|c|c|c|}
\hline Market & Period & Parameter & $\mathrm{P} / \mathrm{E}$ & $\begin{array}{c}\text { Return } \\
(\%)\end{array}$ \\
\hline \multirow{2}{*}{ United States of America } & \multirow{2}{*}{ December/1971 } & 10-year interest rate & 16.81 & 5.95 \\
\hline & & S\&P 500 & 19.38 & 5.16 \\
\hline \multirow{2}{*}{ Brazil } & \multirow{2}{*}{ December/2004 } & Selic Rate & 5.63 & 17.75 \\
\hline & & Ibovespa & 22.12 & 4.52 \\
\hline
\end{tabular}

Ibovespa = Bovespa Index; Selic = Special System for Settlement and Custody.

Source: Economatica ${ }^{\circledR}$ and Brazilian Central Bank.

The Special System for Settlement and Custody (Selic) rate was used for the Brazilian market in a comparable way to the nominal rate of approximately risk-free fixed income valid for Brazilian assets. It is observed that an investor who was concerned about the returns to be derived from his/her investments on December 2004 should not invest in a stock whose price was greater than 5.63 times the company's expected earnings (earnings yield lower than $17.75 \%$ ).

Analyzing how many listed stocks lay at particular P/E thresholds in the Brazilian market at the end of 2004, the result presented in Table 3 was obtained.

Table 3

Number of stocks per price/earnings (P/E) threshold in 2004

\begin{tabular}{ccccc}
\hline $\begin{array}{c}\text { Number of stocks } \\
\text { with } \mathbf{P} / \mathbf{E} \text { data }\end{array}$ & $\begin{array}{c}\text { Number of stocks } \\
\text { with } \mathbf{P} / \mathbf{E}<\mathbf{0}\end{array}$ & $\begin{array}{c}\text { Number of stocks with } \\
\mathbf{0}<\mathbf{P} / \mathbf{E}<\mathbf{6}\end{array}$ & $\begin{array}{c}\text { Number of stocks with } \\
\mathbf{0}<\mathbf{P} / \mathbf{E}<\mathbf{7}\end{array}$ & $\begin{array}{c}\text { Number of stocks with } \\
\mathbf{0}<\mathbf{P} / \mathbf{E}<\mathbf{8}\end{array}$ \\
\hline 467 & 106 & 109 & 137 & 164 \\
\hline
\end{tabular}

Source: Economatica ${ }^{\circledR}$.

In Table 3 it is verified that for 2004 the thresholds of 6,7 , or 8 were reasonably selective. These thresholds are in line with Graham's idea of limiting oneself to purchasing stocks that offered a $\mathrm{P} / \mathrm{E}$ level close to that offered by the fixed income market (5.63 at the end of 2004).

Despite the fact that at the time Graham elaborated the filters he suggested a lower P/E than both the S\&P
500 average and that of the interest rates, adopting the same system in Brazil would leave the analysis with fewer than 109 stocks, thus being excessively restrictive. As the author himself stated that this filter could be reasonably flexible, it is concluded that restricting the selection of stocks to the level of 7 for the P/E ratio would not be very restrictive since it involved a reasonable number of stocks. 


\subsection{Filter: Price/Book Value (P/B)}

Measuring the P/B of the Ibovespa at the end of 2004, it was verified that the Brazilian market presented an average ratio of 1.23 . In order to be able to ensure an interesting level for the $\mathrm{P} / \mathrm{B}$ filter in the stock selection, an analysis was carried out of the number of stocks among the 423 with $\mathrm{P} / \mathrm{B}$ data in the Economatica ${ }^{\oplus}$ database that met particular filter levels at the end of 2004 (Table 4).

Table 4

Number of stocks by level of price/book value $(P / B)$

\begin{tabular}{ccccc}
\hline $\begin{array}{c}\text { Number of stocks with } \\
\mathbf{P} / \mathbf{B}<\mathbf{0 . 5 0}\end{array}$ & $\begin{array}{c}\text { Number of stocks with } \\
\mathbf{P} / \mathbf{B}<\mathbf{0 . 7 5}\end{array}$ & $\begin{array}{c}\text { Number of stocks with } \\
\mathbf{P} / \mathbf{B}<\mathbf{1 . 0 0}\end{array}$ & $\begin{array}{c}\text { Number of stocks with } \\
\mathbf{P} / \mathbf{B}<\mathbf{1 . 2 5}\end{array}$ & $\begin{array}{c}\text { Number of stocks with } \\
\mathbf{P} / \mathbf{B}<\mathbf{1 . 5 0}\end{array}$ \\
\hline 64 & 119 & 174 & 221 & 253 \\
\hline
\end{tabular}

Source: Economatica ${ }^{\circledR}$.

Table 4 leaves it evident that in 2004 the P/B threshold of 1.00 does not appear to be excessively restrictive, since 174 stocks met this criterion.

As Graham had suggested that high $\mathrm{P} / \mathrm{B}$ ratios could be accepted if the P/E ratio was sufficiently discounted, suggesting limiting the value of the product between the $\mathrm{P} / \mathrm{E}$ and $\mathrm{P} / \mathrm{B}$ multiples to the coherent thresholds for each one of them, in this paper the same formulation was adopted, enabling the stocks that present $\mathrm{P} / \mathrm{B}$ ratios higher than 1.00 to be considered eligible for the portfolios as long as their $\mathrm{P} / \mathrm{E} \times \mathrm{P} / \mathrm{B}$ multiple was not higher than 7.00.

\subsection{Additional Filter: Liquidity}

Based on the understanding that a portfolio with 10 assets is already sufficiently diversified, an eighth filter was added as a contribution of this study to Graham's selection method, which consists of choosing only those companies that were traded at least once over the course of 2004, thus favoring stocks for the portfolios in accordance with their liquidity level in that same year. From the stocks selected in each filter, only the 10 most liquid ones were chosen.

This additional restriction is similar to the strategy suggested for the reality of professional investment managers, since by holding a relevant position in a company whose stocks are traded little they would probably face difficulties in realizing their profit by selling their stocks after a price rise. Their own selling efforts could substantially reduce the price of the stocks, eliminating part of the gains obtained. Thus, liquidity can be understood as a risk of investing in stocks, especially in the Brazilian market, in which various stocks have low tradability, and even when selected by the other filters they should present a minimally satisfactory level of liquidity to be considered sufficiently safe investments.

Graham managed the risk of low liquidity of some stocks by buying small quantities of each one of them, resulting in the portfolios having up to 100 stocks.

\subsection{Metrics Used in the Portfolio Evaluation}

As a proxy variable for the return on the risk free asset, the effective Selic rate communicated by the Brazilian Central Bank was used. The discrete monthly returns for each portfolio, for the Ibovespa, and for the Selic were measured.

The volatilities of the portfolios were measured using the SD of the monthly returns. As it was considered that in the portfolios analyzed the idiosyncratic risk had already been eliminated, their risk was also evaluated in terms of beta, with their Jensen's alpha ( $\alpha$ ) being measured using the regressions of excess returns on the portfolios over the risk free asset against the excess return on the Ibovespa over the risk free asset.

The Sharpe ratio was used for the portfolios, thus seeking to evaluate the dominance of the portfolios over each other and the market index. 


\section{RESULTS}

\subsection{Application of Each Criterion}

The first part of the analysis consisted of verifying, among the companies listed, those to which each one of the criteria applied separately, thus forming a portfolio with only the 10 most liquid stocks that met criterion 1 , then the 10 most liquid stocks that only met criterion 2 , and so on. In the verification period (May $2^{\text {nd }}$ of 2005 to April $30^{\text {th }}$ of 2015), the total return on the Ibovespa was $126.34 \%$ and the Selic rate was $197.08 \%$. The values found by trying to identify what was the ability of each one of the filters to generate excess returns over the market index based on the portfolios elaborated are described in Table 5.

Table 5

Bovespa Index (Ibovespa) and isolated filters - return and volatility

\begin{tabular}{|c|c|c|c|c|c|}
\hline \multirow[t]{2}{*}{ Portfolio } & & \multirow[t]{2}{*}{$\begin{array}{l}\text { Return in the period } \\
(\%)\end{array}$} & \multirow[t]{2}{*}{$\begin{array}{c}\text { Excess return over } \\
\text { the Ibovespa } \\
(\%)\end{array}$} & \multicolumn{2}{|c|}{$\begin{array}{l}\text { Annualized values in the period } \\
\qquad(\%)\end{array}$} \\
\hline & & & & Return & Volatility \\
\hline Ibovespa & & 126.34 & - & 8.51 & 22.21 \\
\hline \multirow{7}{*}{ Only applying filters } & 1 & 233.58 & 47.38 & 12.80 & 23.15 \\
\hline & 2 & 22.85 & -45.72 & 2.08 & 29.70 \\
\hline & 3 & 239.97 & 50.21 & 13.02 & 21.86 \\
\hline & 4 & 234.43 & 47.76 & 12.83 & 23.05 \\
\hline & 5 & 260.90 & 59.45 & 13.69 & 23.84 \\
\hline & 6 & 40.34 & -38.00 & 3.45 & 27.48 \\
\hline & 7 & 278.14 & 67.07 & 14.23 & 22.36 \\
\hline
\end{tabular}

$a=$ annualized volatility calculated based on monthly returns.

Source: Elaborated by the authors.

In order for it to be clear what the excess return generated by the use of the filters is, the difference in return was measured between the portfolios obtained by applying only each one of the filters indicated and the
Ibovespa, in accordance with the geometric composition of the returns. It was thus verified how much more the Ibovespa should yield to achieve the return of the portfolio studied. This ratio is given by:

$$
E G R_{i}=\left[\left(1+P R_{i}\right)\right] /\left[\left(1+R_{\text {Ibovespa }}\right)\right]-1
$$

in which $E G R_{i}$ is the excess geometric return over the Ibovespa of filter $i, P R_{i}$ is the return on the portfolio only applying filter $i$, and $R_{\text {Ibovespa }}$ is the return on the Ibovespa in the period. It is observed that, with the exception of filters 2 (current ratio higher than 1.22) and 6 (P/E less than or equal to 7 ), all the others managed to generate positive excess returns.

To calculate the Sharpe ratios for each portfolio, the excess historical average monthly returns over the Selic rate for the same month were used, divided by the average monthly volatility, as shown in Table 6. 
Table 6

Bovespa Index (Ibovespa) and isolated filters - Sharpe and regressions

\begin{tabular}{|c|c|c|c|c|c|c|}
\hline \multirow[b]{2}{*}{ Portfolio } & & \multicolumn{3}{|c|}{ Average monthly values for the period } & \multicolumn{2}{|c|}{ Regression parameters } \\
\hline & & $\begin{array}{c}\text { Return } \\
(\%)\end{array}$ & $\begin{array}{c}\text { Volatility } \\
(\%)\end{array}$ & Sharpe & $\begin{array}{c}\text { Alpha } \\
(\%)\end{array}$ & Beta \\
\hline Ibovespa & & 0.68 & 6.41 & -0.0031 & 0.00 & 1.0000 \\
\hline \multirow{7}{*}{ Applying only filters } & 1 & 1.01 & 6.68 & 0.0479 & 0.36 & 0.9764 \\
\hline & 2 & 0.17 & 8.57 & -0.0425 & -0.49 & 1.1617 \\
\hline & 3 & 1.02 & 6.31 & 0.0494 & 0.41 & 0.9173 \\
\hline & 4 & 1.01 & 6.66 & 0.0481 & 0.38 & 0.9639 \\
\hline & 5 & 1.08 & 6.88 & 0.0579 & 0.42 & 1.0050 \\
\hline & 6 & 0.28 & 7.93 & -0.0385 & -0.37 & 1.0911 \\
\hline & 7 & 1.11 & 6.45 & 0.0637 & 0.72 & 0.6846 \\
\hline
\end{tabular}

$\mathrm{a}=$ the monthly volatility is the standard deviation of the monthly returns.

Source: Elaborated by the authors.

This first reading shows that when picking stocks in the Brazilian market practically all the filters suggested by Graham managed to generate more efficient portfolios in terms of risk/return for investors, with filters 2 (current ratio higher than 1.22) and $6(\mathrm{P} / \mathrm{E}$ lower than or equal to 7) being the only exceptions, since they presented negative Sharpe ratios.

It was also observed that filter 7 (P/E x P/B ratio lower than or equal to 7) obtained the highest Sharpe ratio among all the portfolios analyzed, combining the highest average return observed with the second lowest volatility. This portfolio also presented the lowest beta, indicating low exposure to systemic risk, and the highest alpha among all the portfolios elaborated, thus being the most relevant criterion in the stock selection.

\subsection{Applying the Criteria Together}

It could be imagined that all the filters applied simultaneously over all the stocks in the period would generate a different return from the one expected by the composition of the excess returns of each one of the filters. To verify what the result derived from applying the seven filters at the same time is, the seven filters were applied simultaneously and the 10 most liquid stocks in 2004 were selected. The return and risk for this portfolio are presented in Table 7 .

\section{Table 7}

Bovespa Index (Ibovespa) vs. portfolio with all the filters

\begin{tabular}{|c|c|c|c|c|}
\hline \multirow[t]{2}{*}{ Portfolio } & \multirow{2}{*}{$\begin{array}{l}\text { Return in the period } \\
(\%)\end{array}$} & \multirow{2}{*}{$\begin{array}{c}\text { Excess return over } \\
\text { the Ibovespa } \\
(\%)\end{array}$} & \multicolumn{2}{|c|}{$\begin{array}{l}\text { Annualized values in the period } \\
\qquad(\%)\end{array}$} \\
\hline & & & Return & Volatility $^{\mathrm{a}}$ \\
\hline Ibovespa & 126.34 & - & 8.51 & 22.21 \\
\hline Portfolio with all the filters & 186.43 & 26.55 & 11.10 & 16.52 \\
\hline
\end{tabular}

$\mathrm{a}=$ annualized volatility calculated based on the monthly returns.

Source: Elaborated by the authors.

Observing the excess return generated when the filters are used simultaneously, it is perceived that applying each one of the filters separately was insufficient to attribute the excess return performance observed in a portfolio with all the filters, in order to be able to identify which filters were most relevant in the stock selection.
When seeking an alternative approach to carry out this attribution of the excess return from applying the seven filters simultaneously, this could be based on the performance obtained by the portfolio with all the filters and removing them one by one, reaching the data in Table 8. 
Table 8

Portfolio with all the filters and analysis of each filter - return and volatility

\begin{tabular}{|c|c|c|c|c|c|}
\hline \multirow{2}{*}{\multicolumn{2}{|c|}{ Portfolio }} & \multirow{2}{*}{$\begin{array}{l}\text { Return in the period } \\
(\%)\end{array}$} & \multirow{2}{*}{$\begin{array}{c}\text { Return attributable to } \\
\text { the filter removed } \\
(\%)\end{array}$} & \multicolumn{2}{|c|}{$\begin{array}{l}\text { Annualized values in the period } \\
(\%)\end{array}$} \\
\hline & & & & Return & Volatility \\
\hline \multicolumn{2}{|c|}{ Portfolio with all the filters } & 186.43 & - & 11.10 & 16.52 \\
\hline \multirow{7}{*}{ Removing only filters } & 1 & 186.43 & 0.00 & 11.10 & 16.52 \\
\hline & 2 & 146.48 & 16.21 & 9.44 & 17.62 \\
\hline & 3 & 78.87 & 60.13 & 5.99 & 26.28 \\
\hline & 4 & 257.54 & -19.89 & 13.59 & 16.60 \\
\hline & 5 & 212.31 & -8.29 & 12.06 & 17.50 \\
\hline & 6 & 186.43 & 0.00 & 11.10 & 16.52 \\
\hline & 7 & 220.33 & -10.59 & 12.35 & 26.17 \\
\hline
\end{tabular}

$\mathrm{a}=$ annualized volatility calculated based on monthly returns.

Source: Elaborated by the authors.

In the same way as in Table 5, in order to measure the return attributable to each filter, the return on each portfolio was compared with the total return resulting from the simultaneous application of all the filters, in accordance with the formulation:

$$
E R_{i}=\left[\left(1+R_{\text {Portfolio }}\right)\right] /\left[\left(1+P R_{i}\right)\right]-1
$$

in which $E R_{i}$ is the excess return attributable to filter $i$, $R_{\text {Portfolio }}$ is the return on the portfolio with all the filters applied simultaneously, and $P R_{i}$ is the return on the portfolio without filter $i$.

The relevance of the contribution of filters 2 (current ratio higher than 1.22) and 3 (only profits in the last five years) was verified in terms of difference in performance in Table 8. In the case of filters 4 (uninterrupted dividends in the last five years), 5 (10-year earnings growth of $30 \%$ ), and 7 (P/E x P/B lower than or equal to 7), since when they were removed portfolios with even higher returns were obtained, it can be understood that these filters are generating negative excess returns in a stock selection that already contained the other filters. Criteria 1 (annual revenue higher than $\mathrm{R} \$ 300$ million) and 6 (P/E lower than or equal to 7) were not relevant, since they presented the same portfolio as the one obtained when the seven filters were applied simultaneously.

The portfolio elaborated with all the filters (or excluding only filters 1 or 6) appears to be an inviting investment alternative, since it presents the lowest volatility of all the portfolios, besides presenting one of the highest returns.

In order to be able to show the dominance among the portfolios analyzed, Table 9 provides the Sharpe ratios for the portfolios, as well as the alpha and beta levels.

Table 9

Portfolio with all the filters and analysis of each filter - Sharpe and regressions

\begin{tabular}{|c|c|c|c|c|c|c|}
\hline \multirow[b]{2}{*}{ Portfolio } & & \multicolumn{3}{|c|}{ Average monthly values for the period } & \multicolumn{2}{|c|}{ Regression parameters } \\
\hline & & $\begin{array}{c}\text { Return } \\
(\%)\end{array}$ & $\begin{array}{c}\text { Volatility } \\
(\%)\end{array}$ & Sharpe & $\begin{array}{c}\text { Alpha } \\
(\%)\end{array}$ & Beta \\
\hline Portfolio & filters & 0.88 & 4.77 & 0.0176 & 0.70 & 0.4210 \\
\hline \multirow{7}{*}{$\begin{array}{l}\text { Removing } \\
\text { only filters }\end{array}$} & 1 & 0.88 & 4.77 & 0.0176 & 0.70 & 0.4210 \\
\hline & 2 & 0.75 & 5.09 & -0.0049 & 0.56 & 0.4561 \\
\hline & 3 & 0.49 & 7.59 & -0.0171 & 0.15 & 0.7223 \\
\hline & 4 & 1.07 & 4.79 & 0.0562 & 0.87 & 0.3941 \\
\hline & 5 & 0.95 & 5.05 & 0.0336 & 0.73 & 0.4412 \\
\hline & 6 & 0.88 & 4.77 & 0.0176 & 0.70 & 0.4210 \\
\hline & 7 & 0.97 & 7.56 & 0.0478 & 0.34 & 0.9137 \\
\hline
\end{tabular}

$\mathrm{a}=$ the monthly volatility is the standard deviation of the monthly returns.

Source: Elaborated by the authors. 
It is observed that applying all the filters together generated a portfolio with a significantly lower level of systemic risk than the market index (0.4210), as well as the portfolios in which only filters 1 or 6 were removed. With the exception of the portfolio elaborated without filter 4 (uninterrupted dividends in the last five years), all the other portfolios (without filters 2 , or 3 , or 5 , or 7 ) presented higher betas, revealing the superiority of the model with all the filters in dealing with systemic risk.

In the comparison of the results obtained by using the filters in isolation or removing them separately, it is evident that filter 3 (only profits in the last five years) is relevant in the selection of assets from the value investing perspective, given that when applied in isolation it was able to generate portfolios with a higher Sharpe ratio than the Ibovespa (as shown in Table 6) and a lower systemic risk (beta). At the same time, when excluded from a selection carried out with all the other filters, it caused a reduction in the Sharpe ratio (as shown in Table 9), as well as an increase in the beta.

When applied in isolation, filter 1 (annual revenue higher than R\$300 million) managed to generate a portfolio with a higher Sharpe ratio than the market index and a slightly lower systemic risk (beta of 0.9764); however, when removed from the joint analysis of the other filters, it did not present alterations in the portfolio composition. This is probably due to the fact that this filter is, in fact, hardly restrictive. It is enough to observe that at the end of 2004, of the 361 companies with revenue data available in the Economatica ${ }^{\circledR}$ system, 220 posted figures higher than $\mathrm{R} \$ 300$ million. The classification level as a large-sized company in terms of revenue may make sense when used as a rule for all corporations in the economy, but when used to select only companies of a relevant size, it may be wise to make this filter more restrictive, with the aim of making it more useful for selecting stocks. This result is in line with Basu (1983) and Fama and French (2005), who stated that size is less relevant than the level of discount on the companies' $\mathrm{P} / \mathrm{E}$ ratios for evaluating the attractiveness of the investment.

With respect to filter 4 (uninterrupted dividends in the last five years), despite the fact that when applied in isolation it managed to produce higher results than the market index in terms of Sharpe ratio and a slightly lower systemic risk (beta of 0.9639), it is seen that when removed from the joint analysis of the other filters, it enabled the creation of an even better portfolio than the model for all the filters simultaneously. This shows that the Graham model could be improved for the Brazilian market over the horizon analyzed, removing the restriction of payment of dividends in the last five years. Its relevance, when removed in isolation, is very probably related to the fact that many Brazilian companies were able, over the last five years of the analysis period, to reduce the payments of dividends (or even pay them irregularly), and with the money kept by the company, generate even better results over the verification period. Thus, it cannot be said that this is an effectively necessary criterion for the elaboration of value portfolios in the Brazilian market in the period analyzed.

Filter 5 (10-year earnings growth of 30\%) presented the same impacts on the construction of the portfolios: when applied in isolation, it was able to generate much more interesting results than the Ibovespa, both in terms of Sharpe ratio and in terms of alpha. However, when removed in isolation from the model with all the filters, it improved the results that would be obtained by the model in terms of Sharpe ratio, making it clear than a more adequate adaptation of the Graham model for the Brazilian market should not require companies to present earnings growth in the last 10 years of more than $30 \%$ a year.

With respect to filter 2 (current ratio higher than 1.22), when applied in isolation it was not able to generate a superior portfolio than the market portfolio, and so it can be deduced that this filter would be irrelevant in the selection of a portfolio of stocks. However, when removed from the model that used all the filters simultaneously, it generated an inferior portfolio in all the metrics used. Despite the contradictory results, it can be concluded that the model with all the filters is better adapted to the Brazilian reality in the analysis period when the stock selection is restricted to companies with higher current ratio levels than the market median.

Filter 6 (P/E lower than or equal to 7) was shown to be unable to select companies with the prospects of favorable returns in the Brazilian market, since when used in isolation it generated a portfolio with a lower return than the market index and with a higher risk, both in terms of total risk (volatility) and in terms of systemic risk (beta). One of the potential reasons may be the fact that many of the companies have a low $\mathrm{P} / \mathrm{E}$ due to negative prospects for their future earnings. Thus, some of the companies that had a low $\mathrm{P} / \mathrm{E}$ ultimately proved to be failed investment alternatives. In addition, when this criterion was removed from the joint use of the other filters, it did not influence the portfolio composition, presenting the same parameters as the model with all the filters applied together. Analyzing the portfolios obtained via the simulations, it was observed that this filter is overridden by filter 7 ( $\mathrm{P} / \mathrm{E} \times \mathrm{P} / \mathrm{B}$ ratio lower than or equal to 7$)$, so that in any selection in which filter 7 
acts, the presence of the $\mathrm{P} / \mathrm{E}$ filter becomes unnecessary.

From analyzing the results obtained by filter 7 (P/E $\mathrm{x} P / \mathrm{B}$ lower than or equal to 7 ), we see that despite the fact that when applied in isolation it produced superior results to the Ibovespa (both in terms of Sharpe ratio and in terms of alpha and beta), when removed from the model with the other filters a portfolio was generated with a better Sharpe ratio than the portfolio with all the filters, making its irrelevance in the selection of stocks evident when the other filters are used.

It is observed that the investment methodology guided by value investing makes sense in the Brazilian market, since compiling a portfolio composed of companies with a low short term credit risk, and therefore higher current ratio than the market median (filter 2), and that present a sufficiently long history of profits (filter 3), presents a much more attractive behavior than the market index in terms of risk adjusted return (measured by the Sharpe ratio). It is thus clear that these are the effectively relevant filters for picking stocks in the Brazilian market.

The relevance of value investing as an investment strategy for the Brazilian stock market was verified, since the result obtained by the filters based on the principles of a value strategy was able to generate a portfolio that was dominant over the market index in terms of Sharpe ratio.

The strong dominance of the portfolio with all the filters over the Ibovespa appears to be sufficiently convincing evidence that the criteria suggested by Graham are able to reduce the risk that the investor is exposed to, as well as presenting a significantly higher return than the market index, thus contradicting the efficient markets hypothesis and reinforcing the validity of value investing in the Brazilian market.

It was observed that the most relevant filters in the stock selection method proposed by Graham were filters 2 (current ratio higher than 1.22) and 3 (only profits in the last five years). Similarly, thinking of which filters could be ignored in the stock selection, it can be concluded that filters 1 (large size) and 6 (P/E lower than or equal to 7) enter into this classification, since when they were removed from a selection with the other filters they did not generate alterations in the portfolio composition.

At the same time, since when they were removed from the selection with all the filters, filters 4 (uninterrupted dividends in the last five years), 5 (10-year earnings growth of $30 \%)$, and 7 (P/E $\times$ P/B lower than or equal to 7) generated better portfolios in terms of risk adjusted return, it can be understood that a model without these filters produces superior results to a classification that uses them in the stock selection, thus enabling it to be concluded that these filters are equally undesirable when picking stocks.

In addition, it can be affirmed that the stock selection model proposed by Graham is valid in the current Brazilian market, since the portfolios elaborated in accordance with this methodology were able to present a higher risk adjusted return (Sharpe ratio) than the market, besides showing a positive alpha and exposure to systemic risk (beta) lower than 1.00, making the validity of value investing as a methodology for picking stocks evident, and thus answering the question/problem of this study.

\section{CONCLUSIONS}

This article returned to the discussion of the reasons for adopting a value investing strategy according to the selection criteria suggested by Benjamin Graham, that is, selecting only good and solid companies by requiring a consistent and growing history of earnings, payment of dividends, a large size, and comfortable current liquidity. With this, the aim was to seek to eliminate those companies that presented difficult to measure fundamental risks. By restricting the analysis universe to companies that had lower risks than the market average and elaborating portfolios with more discounted companies in terms of $\mathrm{P} / \mathrm{E}$ and $\mathrm{P} / \mathrm{B}$, it was observed that these portfolios also presented preferable results to the market index, both in terms of systemic risk (betas) and in terms of risk adjusted returns (Sharpe ratios).

What could be concluded from this experiment was that the model suggested by Graham (2007) and adapted to the current conditions of the Brazilian market is able to generate portfolios with a risk/return ratio superior to the market index in the period analyzed (May of 2005 to April of 2015). This result was corroborated both by higher returns and by lower measures of total risk (volatility) and systemic risk (beta). The quality of the model is derived from its ability to select companies that present better results than the market average.

By seeking to understand what the aims of the selection suggested by Graham are, this study has also deepened the understanding of the model, analyzing each criterion separately and their economic coherence with the time in the Brazilian market. With this, the aim was not only to test the validity of the Graham model for picking stocks in the Brazilian context, but also to adapt it to the Brazilian economic reality based on a historical and economic contextualization. 
In addition, by seeking to identify which filters are most relevant and which play a secondary role in the selection of stocks, this paper sought to contribute to the practical application of the model analyzed, since it helped to simplify the methodology for selecting stocks that could be applied in the Brazilian market.

As its main contribution, this research has provided a validation of the Graham model in the Brazilian context, proving the applicability of value investing. Since the elaboration of the portfolio was not something that was defined in clear guidelines by Graham, this study has also contributed to illustrating an adequate way for stock portfolios to be elaborated from the perspective of his methodology.

Another contribution to the model proposed by Graham was the use of a liquidity filter, with the aim of favoring the selection of more liquid stocks in the market, in order to manage the portfolio risk for the investor if they needed to offload some investment. Liquidity should be seen as an additional risk and the existence of the filter enables the market risks the investor would be exposed to in the case of picking companies with low liquidity to be addressed. It is worth remembering that Graham was willing to buy stocks from companies with little liquidity, addressing this risk via extreme diversification and buying small quantities of each selected stock. An investor that tried to implement this strategy in the Brazilian market would incur transaction costs that could make the financial attractiveness of this investment methodology invalid. Thus, addressing liquidity risk via an additional filter appeared to be a sensible way of implementing the suggested model in Brazil.

This study also sought to contribute to a methodological refinement in order for companies to be classified as value stocks, especially in Brazilian studies. Most of the studies (e.g., Campbell et. al., 2010, Fama \& French, 1992) define value stocks as simply those stocks that present lower general levels of price multiples $(\mathrm{P} / \mathrm{E}$ or $\mathrm{P} / \mathrm{B})$ than the market average, and in this article it was defined, in line with the methodology suggested by Graham currently applied in the Brazilian market, that value stocks should be selected according to additional parameters. The suggestions of this article are that these additional criteria are high current ratio level and a minimum history of five years of consistently profits.

Subsequent studies are needed to reinforce the validity of the value investing model for picking stocks in the Brazilian market. It is recommended that studies that analyze different levels of diversification of portfolios elaborated with the Graham model are carried out in order to certify the optimal diversification level. In addition, despite the value investing guidelines being that investments are carried out passively and held over long time horizons, a performance test for the model for other time horizons would be an important investigation, in that it would demonstrate the applicability of the model and the validity of the investment philosophy in a more unrestrained way.

It is also worth mentioning that a potential limitation of the proposed investment method is the fact that, historically, the returns offered by fixed income investment alternatives can make the attractiveness of investing in stocks questionable in Brazil, since the returns on fixed income assets have always been higher than those of the equity market (in earnings/price terms). This high opportunity cost was also evident in the analysis period of this study, since the cumulative return for the Selic rate in the period was higher than that of the Ibovespa. 


\section{REFERENCES}

Almeida, V. G., Oliveira, P. H., Botrel, P. C., \& Martins, M. (2011). Teste da aplicação de critérios de análise fundamentalista às ações negociadas na Bovespa: 1997-2011. Anais do XIV SemeAD - Seminários em Administração, São Paulo, SP, Brazil. Retrieved from http://www.ead.fea.usp.br/semead/14semead/ resultado/trabalhosPDF/1066.pdf

Artuso, A. R., \& Chaves, A., Neto (2010). O Uso de quartis para a aplicação dos filtros de Graham na Bovespa (1998-2009). Revista Contabilidade \& Finanças, 21(52).

Basu, S. (1977). Investment performance of common stocks in relation to their price earnings ratios: a test of the efficient market hypothesis. The Journal of Finance, 32(3), 663-682.

Basu, S. (1983). The relationship between earnings' yield, market value and return for NYSE common stocks: further evidence. Journal of Financial Economics, 12(1), 129-156.

Battaglia, T. K. (2013). Desempenho de carteiras $1 / \mathrm{N}$ selecionadas aleatoriamente (Master's Dissertation). Instituto Coppead de Administração, Universidade Federal do Rio de Janeiro, Rio de Janeiro. Retrieved from http://www.coppead.ufrj.br/ upload/publicacoes/Theo_Battaglia.pdf

Bloomfield, T., Leftwich, R., \& Long, J. (1977). Portfolio strategies and performance. Journal of Financial Economics, 5(2), 201218.

Brito, N. R. (1981). O efeito de diversificação de risco no mercado acionário brasileiro. RAUSP, 16(2).

Campbell, J. Y., Polk, C., \& Vuolteenaho, T. O. (2010). Growth or glamour? Fundamentals and systematic risk in stock returns. The Review of Financial Studies, 23(1), 305-344.

Ceretta, P. S., \& Costa, N., Jr. (1998). Comportamento do mercado de ações no período de 1968-1997. Revista de Negócios, 3(2), 17-25.

Chan, L., \& Lakonishok, J. (2004). Value and growth investing : review and update. Financial Analysts Journal, 60(1), 71-86.

Chan, L., Hamao, Y., \& Lakonishok, J. (1991). Fundamentals and stock returns in Japan. The Journal of Finance, 46(5), 17391764.

Damodaran, A. (2006). Mitos de investimentos. São Paulo, SP: Financial Times Prentice Hall.

Damodaran, A. (2007). Filosofias de investimento - Estratégias bem-sucedidas e os investidores que as fizeram funcionar. Rio de Janeiro, RJ: Qualitymark.

DeMiguel, V., Garlappi, L., \& Uppal, R. (2009). Optimal versus naive diversification: how inefficient is the $1 / \mathrm{N}$ portfolio strategy? The Review of Financial Studies, 22(5), 1915-1953.

Evans, J. L., \& Archer, S. H. (1968). Diversification and the reduction of dispersion: an empirical analysis. The Journal of Finance, 23(5), 761-767.

Fama, E. (1970). Efficient capital markets: a review of theory and empirical work. The Journal of Finance, 25(2), 383-417.

Fama, E., \& French, K. (1992). The cross-section of expected stock returns. The Journal of Finance, 47(2),427-465.

Fama, E., \& French, K. (1998). Value versus growth: the international evidence. The Journal of Finance, 53(6), 19751999.
Fama, E., \& French, K. (2005). The value premium and the CAPM. Retrieved from http://dx.doi.org/10.2139/ssrn.686880

Fisher, L., \& Lorie, J. (1970). Some studies of variability of returns on investments in common stocks. The Journal of Business, 43(2), 99-134.

Graham, B. (2007). O investidor inteligente (updated with new comments from J. Zweig; L. Sette, trans.). Rio de Janeiro, RJ: Nova Fronteira.

Graham, B., \& Dodd, D. (2009). Security analysis (6th ed.) New York, NY: McGraw-Hill.

Greenwald, B., Kahn, J., Sonkin, P., \& Biema, M. (2001). Value investing : from Graham to Buffett and Beyond. Hoboken, NJ: John Wiley \& Sons.

Haugen, Robert A. (1995). The new finance: the case against efficient markets. Upper Saddle River, NJ: Prentice-Hall.

Jaffe, J., Keim, D. \& Westerfield, R. (1989). Earnings yields, market values, and stock returns. The Journal of Finance, 44(1), 135148.

Jensen, M. (1968). The performance of mutual funds in the period of 1945-1964. The Journal of Finance, 23(2), 389-416.

Klerck, W., \& Maritz, A. (1997). A Test of Graham's stock selection criteria on industrial shares traded on the JSE. Investment Analysts Journal, 26(45), 25-33.

Lakonishok, J., Shleifer, A., \& Vishny, R. (1994). Contrarian investment, extrapolation, and risk. The Journal of Finance, 49(5), 1541-1578.

Law n. 11,638, of December $28^{\text {th }}$ of 2007 (2007, December $\left.28^{\text {th }}\right)$. Alters and revokes the arrangements of Law n. 6,404, of December $15^{\text {th }}$ of 1976 , and of Law n. 6,385, of December $7^{\text {th }}$ of 1976, and extends to large-sized companies arrangements related to the elaboration and disclosure of financial statements. Retrieved from http://www.planalto.gov.br/ ccivil_03/_ato2007-2010/2007/lei/111638.htm

Markowitz, H. (1952). Portfolio Selection. The Journal of Finance, 7(1), 77-91.

Martins, H., \& Gava, A. (2009). Quantas ações são necessárias para se obter um portfólio diversificado no mercado de ações brasileiro? Um estudo empírico. XXIX National Product Engineering Meeting. Salvador, BA, Brazil. Retrieved from http://www.abepro.org.br/biblioteca/enegep2009_TN_ WIC_093_631_13430.pdf

Nicholson, S. F. (1960). Price-earnings ratios. The Financial Analysts Journal, 16(4), 43-45.

Nicholson, S. F. (1968). Price-earnings ratios in relation to investment results. The Financial Analysts Journal, 24(1), 105109.

Oppenheimer, H. (1984). A test of Ben Graham's stock selection criteria. Financial Analysts Journal, 40(5), 68-74.

Passos, V., \& Pinheiro, J. L. (2009). Estratégias de investimento em bolsas de valores: uma pesquisa exploratória na visão fundamentalista de Benjamin Graham. Revista Gestão \& Tecnologia, Pedro Leopoldo, 9(1), 1-16.

Rea, J. (1977). Remembering Benjamin Graham - teacher and friend. The Journal of Portfolio Management Summer, 3(4), 66-72. 
Santiago, D. C. (2013). O desempenho de carteiras igualmente ponderadas com quantidades pequenas de ações (Master's Dissertation). Instituto Coppead de Administração, Universidade Federal do Rio de Janeiro, Rio de Janeiro. Retrieved from http://www.coppead.ufrj.br/upload/ publicacoes/Diogo_Santiago.pdf

Santiago, D. C., \& Leal, R. P. C. (2014). Carteiras igualmente ponderadas com poucas ações e o pequeno investidor. Rio de Janeiro, RJ: UFRJ/Coppead.
Testa, C. (2011). Aplicação da estratégia de investimento de Graham à BM\&FBovespa para o pequeno investidor. Anais do XIV SemeAD - Seminários em Administração, São Paulo, SP, Brazil. Retrieved from http://www.ead.fea.usp.br/ semead/14semead/resultado/trabalhosPDF/469.pdf

Thomé, C., Neto, Leal, R. P. C, \& Almeida, V. S. (2011). Um índice de mínima variância de ações brasileiras. Economia Aplicada, 15(4), 535-557.

Sharpe, W. (1966). Mutual fund performance - Part 2: supplement Yee, K. (2008). Deep-value investing, fundamental risks, and the on security prices. The Journal of Business, 39(1), 119-138. margin of safety. The Journal of Investing, 17(3), 35-46. 


\section{ANNEX}

Portfolios resulting from the filters

\begin{tabular}{|c|c|c|c|c|c|c|c|c|c|c|c|c|c|c|c|}
\hline \multirow[t]{2}{*}{ Stock } & \multicolumn{7}{|c|}{$\begin{array}{l}\text { Portfolios resulting from } \\
\text { applying the filters in isolation }\end{array}$} & \multirow[t]{2}{*}{$\begin{array}{l}\text { Portfolio with } \\
\text { the seven filters } \\
\text { simulataneously }\end{array}$} & \multicolumn{7}{|c|}{$\begin{array}{l}\text { Portfolios resulting from } \\
\text { removing the filters in isolation }\end{array}$} \\
\hline & 1 & 2 & 3 & 4 & 5 & 6 & 7 & & 1 & 2 & 3 & 4 & 5 & 6 & 7 \\
\hline ACES4 & & & & & & $x$ & & & & & & & & & \\
\hline ALPA3 & & & & & & & & & & & & & & & $x$ \\
\hline AMBV4-Old & $x$ & & $X$ & $X$ & $x$ & & & & & & & & & & \\
\hline ARCZ3 & & & & & & & & & & & & & & & $x$ \\
\hline BBDC4 & $x$ & & $X$ & $X$ & $x$ & & & & & & & & & & \\
\hline BRIV4 & & & & & & & & & & $x$ & & & & & \\
\hline BRTP4 & & $x$ & $X$ & & & & & & & & & & & & \\
\hline CEDO4 & & & & & & & & $X$ & $X$ & $x$ & & & & $X$ & \\
\hline CEEB3 & & & & & & & & $x$ & $x$ & $x$ & & $x$ & $x$ & $x$ & \\
\hline CESP5 & & & & & & & $x$ & & & & & & & & \\
\hline$\overline{\mathrm{CIQU} 4}$ & & & & & & & & $x$ & $x$ & $x$ & & $x$ & $X$ & $x$ & \\
\hline CMET4 & & & & & $x$ & & & & & & & & & & \\
\hline CMIG4 & $x$ & & & $X$ & $X$ & & & & & & & & & & \\
\hline CPLE6 & & & & & & & $x$ & & & & & & & & \\
\hline CSNA3 & $x$ & $x$ & & $X$ & $x$ & & & & & & & & & & \\
\hline CSTB4 & & $x$ & & & & $x$ & $x$ & & & & $X$ & & & & \\
\hline DPPI4 & & & & & & & & $x$ & $x$ & $x$ & $X$ & $x$ & $x$ & $x$ & $\mathrm{X}$ \\
\hline ELET6 & & & $X$ & $X$ & & & $x$ & & & & & & & & \\
\hline EMBR4 & & $X$ & $X$ & & & & & & & & & & & & \\
\hline FBRA4 & & & & & & & & & & & $x$ & & & & \\
\hline FESA4 & & & & & & & $x$ & $X$ & $X$ & $x$ & $X$ & $x$ & $X$ & $X$ & $X$ \\
\hline GGBR4 & $X$ & $X$ & $\mathrm{X}$ & $X$ & $\mathrm{X}$ & $x$ & & & & & & & & & $\mathrm{X}$ \\
\hline GOAU3 & & & & & & & & $x$ & $X$ & $x$ & $x$ & $x$ & $X$ & $x$ & \\
\hline GOAU4 & & & & & & $x$ & & & & & & & & & $\mathrm{X}$ \\
\hline IGUA6 & & & & & & & & $x$ & $x$ & $x$ & $x$ & $X$ & $X$ & $x$ & $\mathrm{X}$ \\
\hline ITUB4 & $x$ & & $X$ & $x$ & $x$ & & & & & & & & & & \\
\hline MAGS5 & & & & & & & $x$ & $x$ & $x$ & $X$ & $x$ & $X$ & $X$ & $x$ & $X$ \\
\hline MOAR3 & & & & & & & & $x$ & $x$ & & & $X$ & $X$ & $X$ & \\
\hline MRSL4 & & & & & & & & & & & $X$ & & & & \\
\hline PETR4 & $x$ & $x$ & $X$ & $X$ & $X$ & $x$ & & & & & & & & & $X$ \\
\hline PLTO6 & & & & & & & & & & & & & $X$ & & \\
\hline PTIP4 & & & & & & $x$ & $x$ & & & & & & & & \\
\hline PTPA4 & & & & & & & & & & & & $x$ & & & \\
\hline RIPI4 & & & & & & & $x$ & & & & & & & & \\
\hline ROMI3 & & & & & & & & $x$ & $x$ & $X$ & $X$ & $X$ & $X$ & $X$ & \\
\hline ROMI4 & & & & & & & & & & & & & & & $X$ \\
\hline SBSP3 & & & & & & & $x$ & & & & & & & & \\
\hline SUZB5 & & & & & & $X$ & & & & & & & & & \\
\hline TCOC4 & & $x$ & $X$ & & & $X$ & & & & & & & & & \\
\hline TIMP3 & & & & & & $x$ & & & & & & & & & \\
\hline TNLP4 & $x$ & $x$ & & $X$ & & & & & & & & & & & \\
\hline TPRC6 & & & & & & & $x$ & & & & & & & & \\
\hline USIM3 & & & & & & & & & & & $X$ & & & & \\
\hline USIM5 & $x$ & $X$ & & $X$ & $X$ & $X$ & & & & & & & & & \\
\hline VALE5 & $x$ & $x$ & $X$ & & $x$ & & & & & & & & & & \\
\hline
\end{tabular}

Note: the letter " $x$ " marked for each one of the stocks denotes its participation in the portfolio mentioned.

$a=$ the number of the filter indicates the filter used in the elaboration of each one of the portfolios; $b=$ the number of the filter indicated shows the filter removed in the elaboration of each one of the portfolios.

Source: Economatica ${ }^{\circledR}$. 